\title{
Polyhydroxyalkanoate Synthesis by Recombinant Escherichia coli JM109 Expressing PHA Biosynthesis Genes from Comamonas sp. EB172
}

\author{
Lian-Ngit Yee ${ }^{1}$, Tabassum Mumtaz ${ }^{2}$, Mitra Mohammadi', Lai-Yee Phang ${ }^{1}$, Yoshito Ando ${ }^{3}$, Abdul Rahim Raha ${ }^{1}$, Kumar Sudesh ${ }^{4}$, Hidayah
} Ariffin $^{1}$, Mohd Ali Hassan ${ }^{1,5}$ and Mohd Rafein Zakaria ${ }^{1 *}$

${ }^{1}$ Faculty of Biotechnology and Biomolecular Sciences, Universiti Putra Malaysia, 43400 Serdang, Selangor, Malaysia

${ }^{2}$ Microbiology and Industrial Irradiation Division, Bangladesh Atomic Energy Commission, Bangladesh

${ }^{3}$ Eco-Town Collaborative R\&D Center for the Environment and Recycling, Kyushu Institute of Technology, Hibikino 2-4, Wakamatsu, Kitakyushu, Fukuoka 808-0196, Japan

${ }^{4}$ Ecobiomaterial Research Laboratory, School of Biological Sciences, Universiti Sains Malaysia, 11800 Penang, Malaysia

${ }^{5}$ Faculty of Engineering, Universiti Putra Malaysia, 43400 Serdang, Selangor, Malaysia

\begin{abstract}
Recombinant Escherichia coli JM109 harbouring the polyhydroxyalkanoate (PHA) biosynthesis gene (phaCABco) of Comamonas sp. EB172, an acid tolerant microbe, was examined for the production of PHAs from various carbon sources. The study demonstrated that the recombinant $E$. coli JM109 had the potential to utilize both sugar- and acid-based carbon sources, for the biosynthesis of both poly(3-hydroxybutyrate) $\mathrm{P}(3 \mathrm{HB})$ and poly (3hydroxybutyrate-co-3-hydroxyvalerate) $\mathrm{P}(3 \mathrm{HB}-\mathrm{co}-3 \mathrm{HV}$ ) copolymers. In the shake flask experiments, the strain was capable of producing $\mathrm{P}$ (3HB-co-3HV) copolymer from mixed organic acids, and higher productivities were obtained using glucose compared to mixed acids. However, PHA accumulation was found to be similar, regardless of the carbon source used. Nitrogen supplementation in the medium was found to improve the cell dry weight, but negatively affected the $3 \mathrm{HV}$ formation in copolymer production. Maximum $3 \mathrm{HV}$ monomer $(3 \mathrm{~mol} \%)$ was obtained with $\mathrm{C} / \mathrm{N} \mathrm{42.1}$, using mixed acids as the carbon source. In the $2 \mathrm{~L}$ bioreactor, the productivity and yield based on substrate utilization coefficient were found to be $0.16 \mathrm{~g} \mathrm{PHA} /(\mathrm{L} . \mathrm{h})$ and $0.41 \mathrm{~g} \mathrm{PHA} / \mathrm{g}$ substrate under C/N around 75 , using $20 \mathrm{~g} / \mathrm{L}$ glucose and $0.5 \mathrm{~g} / \mathrm{L}$ ammonium sulphate, respectively. The polymer produced by the recombinant strain had molecular weight in the range of $8.5 \times 105$ to $1.4 \times 106 \mathrm{Da}$. Overall, the ability of the recombinant $E$. coli JM109 to utilize both glucose and mixed acids, has widened its substrate selection for fermentation, including the opportunity to use renewable biomass.
\end{abstract}

Keywords: Recombinant; PhaCABco; Mixed acids; Polyhydroxyalkanoate; Comamonas sp. EB172

\section{Introduction}

Polyhydroxyalkanoates (PHAs) are energy storage, hydrophobic granules that can be accumulated by many microorganisms [1-4]. PHAs are biodegradable, biocompatible thermoplastics, and hence, these biopolyesters are not only the potential alternative candidates for recalcitrant synthetic plastics, but also present long-term benefits for environmental pollution issues. However, the high cost for PHA production compared to the availability of low-cost petroleum-based plastic, is the major obstacle to commercialize these biosynthesized PHAs $[5,6]$. The most significant factor for the high production cost of PHAs is the fermentation process, which is mainly due to the cost of raw material as well as the recovery process [7]. A great deal of effort has been made to reduce the production cost by employing superb microbial strains, as well as, developing fermentation and recovery process with cheap carbon sources and non-halogenated solvents, respectively [7-9].

Economic biotechnological PHA formation largely depends on the choice of productive microorganisms and their culture condition. Recently, in our continuous effort of utilizing mixed organic acids derived from palm oil mill effluent (POME) for PHA production, we have produced several reports on the isolation, biosynthesis and characterization of both $\mathrm{P}(3 \mathrm{HB})$ and $\mathrm{P}(3 \mathrm{HB}-\mathrm{co}-3 \mathrm{HV})$ by a local, acid tolerant strain of Comamonas sp. designated as Comamonas sp. EB172 [10-14]. While developing a suitable fermentation strategy to feed mixed acids in its original form (keeping identical ratio as obtained), our focus was also to develop a non-halogenated PHA recovery system, at the end of fed-batch fermentation $[10,15,16]$. However, Comamonas sp. EB172 is known to utilize only fatty acids but not glucose or fructose [13]. Therefore, the three genes involved in the biosynthesis of PHAs by Comamonas sp. EB172 were cloned and characterized [17]. Meanwhile, the PHA biosynthesis genes of Comamonas sp. EB172 had also been cloned and heterologously expressed for its functionality, to demonstrate the ability of the isolated biosynthesis gene on PHA production in E. coli JM109 host.

Recombinant E. coli has commonly been employed for PHA production due to its convenience for genetic manipulation, fast growth, high cell density cultivation and ability to utilize inexpensive carbon sources. The strain has been reported to produce short-chainlength (scl) polyesters containing $\mathrm{C} 4$ or $\mathrm{C} 5$ monomers, such as $\mathrm{P}(3 \mathrm{HB})$, poly(3-hydroxyvalerate) $\mathrm{P}(3 \mathrm{HV})$, poly(4-hydroxybutyrate) $\mathrm{P}(4 \mathrm{HB})$ homopolymer, or the $\mathrm{P}(3 \mathrm{HB}-\mathrm{co}-3 \mathrm{HV})$ copolymer [18] and $\mathrm{P}(3 \mathrm{HB}-\mathrm{co}-$ $4 \mathrm{HB})$ [19]. Nevertheless, recombinant E. coli, containing the phaC1 gene from Pseudomonas aeruginosa, was able to produce mediumchain- length (mcl) PHAs, having C6 to C14 monomers including homopolymers of 3-hydroxyhexanoate $(3 \mathrm{HHx}), 3$-hydroxydodecanoate (3HDD) and terpolymer poly(3-hydroxybutyrate-co-3-

*Corresponding author: Mohd Rafein Zakaria, Faculty of Biotechnology and Biomolecular Sciences, Universiti Putra Malaysia, 43400 Serdang, Selangor, Malaysia Tel: +60 3 89471946; Fax: +60 3 89471184; E-mail: rafein@biotech.upm.edu.my

Received August 26, 2012; Accepted September 21, 2012; Published September 25, 2012

Citation: Yee LN, Mumtaz T, Mohammadi M, Phang LY, Ando Y, et al. (2012) Polyhydroxyalkanoate Synthesis by Recombinant Escherichia coli JM109 Expressing PHA Biosynthesis Genes from Comamonas sp. EB172. J Microb Biochem Technol 4: 103-110. doi:10.4172/1948-5948.1000079

Copyright: (c) 2012 Yee LN, et al. This is an open-access article distributed under the terms of the Creative Commons Attribution License, which permits unrestricted use, distribution, and reproduction in any medium, provided the original author and source are credited 
Citation: Yee LN, Mumtaz T, Mohammadi M, Phang LY, Ando Y, et al. (2012) Polyhydroxyalkanoate Synthesis by Recombinant Escherichia coli JM109 Expressing PHA Biosynthesis Genes from Comamonas sp. EB172. J Microb Biochem Technol 4: 103-110. doi:10.4172/19485948.1000079

hydroxyvalerate-co-hydroxyhexanoate), $\mathrm{P}(3 \mathrm{HB}-\mathrm{co}-3 \mathrm{HV}-\mathrm{co}-3 \mathrm{HHx})$ [20,21], when beta-oxidation gene fadB was deleted [20]. Meanwhile, hybrid polymers containing both scl- and mcl-monomer units such as poly(3-hydroxybutyrate-co-hydroxyhexanoate), $\mathrm{P}(3 \mathrm{HB}-\mathrm{co}-3 \mathrm{HHx})$, produced naturally by Aeromonas caviae, can also be synthesized in recombinant $E$. coli through genetic manipulation [22,23]. For commercial PHA production, recombinant E. coli has also been employed by Metabolix, USA and Jiang Su Nan Tian Co. Ltd, China [24]. Metabolically engineered E. coli can easily express the enzyme involved in PHA biosynthesis, with various monomer compositions. Therefore, E. coli JM109 was chosen to express the PHA biosynthesis genes from Comamonas sp. EB172. The potentiality of this recombinant strain was examined in the shake flasks, and bioreactor studies using both refined and non-refined carbon sources.

In this study, the performance of recombinant E. coli JM109 was examined for $\mathrm{P}$ (3HB-co-3HV) copolymer production, and better cell growth using glucose and mixed organic acids as the carbon sources. The polymer produced was further characterized for its chemical structure and molecular weight. The data reported herewith, may be useful for future work using recombinant strain, with local renewable substrates such as POME and oil palm fronds (OPF) [25].

\section{Materials and Methods}

\section{Bacterial strains, plasmids and culture conditions}

Recombinant E. coli JM109 that harboured plasmid pGEM'phaCABCo containing PHA biosynthesis gene, phaCABCo of Comamonas sp. EB172, was used in this study [17]. E. coli JM109 is a general host for cloning. Through this study, we can observe the substrate or enzyme ability of the cloned genes for the PHA accumulation under various conditions. Hence, simple E. coli bacteria strain is necessary rather than the expression host such as E. coli DH5a. The E. coli $\mathrm{DH} 5$ a can be the strain for future genetic modification and process optimization. Recombinant E. coli JM109 was cultivated at $37^{\circ} \mathrm{C}$ and $200 \mathrm{rpm}$ in the Luria-Bertani medium, comprising the following components: $10 \mathrm{~g}$ casein peptone, $10 \mathrm{~g}$ sodium chloride and $5 \mathrm{~g}$ yeast extract in $1 \mathrm{~L}$ of distilled water. The antibiotic ampicillin (50 $\mu \mathrm{g} / \mathrm{mL}$ ) was added to the culture medium, to maintain the stability of the plasmids.

\section{PHA accumulation in shake flask}

The recombinant E. coli JM109 was pre-cultured in the LuriaBertani medium at $37^{\circ} \mathrm{C}$ and $200 \mathrm{rpm}$ for $14 \mathrm{~h}$, and $10 \%(\mathrm{v} / \mathrm{v})$ of the culture (OD600nm $\approx 3.0$ ) was inoculated into a $250 \mathrm{~mL}$ shake flask, containing $50 \mathrm{~mL}$ of nitrogen-limited mineral salts (MS) medium ( $\mathrm{pH}$ 7.0). The MS medium consisted of (in $\mathrm{g} / \mathrm{L}) 5 \mathrm{~g} \mathrm{KH}_{2} \mathrm{PO}_{4}, 2 \mathrm{~g} \mathrm{~K}_{2} \mathrm{HPO}_{4}$, $1 \mathrm{~g}\left(\mathrm{NH}_{4}\right)_{2} \mathrm{SO}_{4}, 0.4 \mathrm{~g} \mathrm{MgSO} \cdot 7 \mathrm{H}_{2} \mathrm{O}$ and $1 \mathrm{~mL}$ of trace element solution [17]. Ampicillin $(50 \mu \mathrm{g} / \mathrm{mL})$ was added, when it was necessary for plasmid maintenance. Glucose was sterilized separately and was added to the rest of the medium, before inoculation to avoid caramelization effect. The mixtures of three acids (acetic: propionic: $n$-butyric acid) in a ratio of 3:1:1, were sterilized along with other salts in the MS medium, to give a final concentration of $10 \mathrm{~g} / \mathrm{L}$. The mass ratio of 3:1:1 for the mixed organic acids was to simulate anaerobically the fermented POME, as the carbon source [26]. The cultures were cultivated at $37^{\circ} \mathrm{C}$ and $200 \mathrm{rpm}$ for $48 \mathrm{~h}$ in the incubator shaker. The cell growth, cell concentration and final $\mathrm{pH}$ were monitored during the fermentation.

\section{PHA accumulation in $2 \mathrm{~L}$ bioreactor}

The pre-cultured recombinant E. coli JM109 in a 100-mL Luria-
Bertani medium, in a $500-\mathrm{mL}$ shake flask was used as the seed culture. The seed culture was incubated at $37^{\circ} \mathrm{C}$ and agitated at $200 \mathrm{rpm}$ for 14 h. One hundred millilitres $(10 \% \mathrm{v} / \mathrm{v})$ of the seed culture $($ OD $600 \mathrm{~nm} \approx$ 3.0) was inoculated into a $2 \mathrm{~L}$ bioreactor, with a $900-\mathrm{mL}$ MS medium supplemented with $10 \mathrm{~g} / \mathrm{L}, 20 \mathrm{~g} / \mathrm{L}$ glucose or $10 \mathrm{~g} / \mathrm{L}$ mixed acids as the carbon source. Three different concentrations of ammonium sulphate (without nitrogen addition, $0.5 \mathrm{~g} / \mathrm{L}$ and $1.0 \mathrm{~g} / \mathrm{L}$ ) were supplemented in the MS medium. The cells were grown at $37^{\circ} \mathrm{C}$ and $\mathrm{pH} 7$ (controlled using $1 \mathrm{M} \mathrm{NaOH}$ ) throughout the experiment. The dissolved oxygen tension (DOT) level was maintained above $30 \%$ of air saturation, by automatically raising the agitation speed from 150 to $600 \mathrm{rpm}$. The air flow rate was kept at $1 \mathrm{vvm}$ throughout the fermentation. The batch fermentation was cultivated for $24 \mathrm{~h}$, depending on the exhaustion of the carbon sources in the MS broth. The cell growth, cell concentration and PHA accumulation were monitored during the course of the fermentation.

\section{Gas chromatography analysis}

Grown cells were harvested by centrifugation ( $6000 \mathrm{x}$ g, 10 minutes, $4^{\circ} \mathrm{C}$ ), washed with distilled water and lyophilised. The lyophilized cells after methanolysis at $100^{\circ} \mathrm{C}$ for 140 minutes, in the presence of sulphuric acid and methanol (15:85 v/v) [27], were subjected for cellular PHA content and polymer composition by gas chromatography (Shimadzu, GC2014) analysis.

\section{Extraction and purification of polymer from cell}

Polymers were extracted from the lyophilized cells using the modified method of Amirul et al. [28]. One gram of lyophilized cells was stirred overnight in $250 \mathrm{~mL}$ of chloroform at room temperature. The mixture of cell debris and polymers was separated through Whatman No. 1 membrane filter paper, with the pore size of $11 \mu \mathrm{m}$. PHA dissolved in chloroform and was recovered by precipitating using cold methanol, in the ratio of 1:5. The precipitated polymer was filtered using $0.45 \mu \mathrm{m}$ PTFE membrane filter and dried overnight at room temperature. The extracted pure polymer was then characterized for its chemical structure and molecular weight, by proton nuclear magnetic resonance (1HNMR, $500 \mathrm{MHz}$ JEOL JNM-ECP500 FT NMR) and sizeexclusion chromatography (SEC, TOSOH HLC-8120), respectively [29].

\section{Characterization of polymer}

1H NMR spectra were recorded on a $500 \mathrm{MHz}$ JEOL JNM-ECP500 FT NMR. Chloroform-d (CDCl3) was used as a solvent. Chemical shifts were reported as $\delta$ values (ppm) relative to internal tetramethylsilane (TMS) in $\mathrm{CDCl} 3$, unless otherwise stated. The molecular weights of the polymers were measured on a TOSOH HLC-8120 SEC system with refractive index (RI) and ultraviolet (UV, $\lambda=254 \mathrm{~nm}$ ) detectors, under the following conditions: TSKgel Super HM-H linear column (linearity range, 1x103 - 8 x106; molecular weight exclusion limit, 4 $\mathrm{x} 108$ ), chloroform eluent at a flow rate of $0.6 \mathrm{~mL}$ min-1, and column temperature of $40^{\circ} \mathrm{C}$. The calibration curves for SEC analysis were obtained, using polystyrene standards with a low polydispersity (5.0x102, $1.05 \times 103,2.5 \times 103,5.87 \times 103,9.49 \times 103,1.71 \times 104,3.72 \times 104$, 9.89x104, 1.89x105, 3.97x105, 7.07 x105, 1.11x106, TOSOH Corp.).

\section{Data analysis}

Statistical analysis of the experimental results was carried out using MSTAT-C software. Duncan's Multiple Range Test at 5\% $(\mathrm{p}<0.05)$ alpha level was used for mean experimental data comparisons. 
Citation: Yee LN, Mumtaz T, Mohammadi M, Phang LY, Ando Y, et al. (2012) Polyhydroxyalkanoate Synthesis by Recombinant Escherichia coli JM109 Expressing PHA Biosynthesis Genes from Comamonas sp. EB172. J Microb Biochem Technol 4: 103-110. doi:10.4172/19485948.1000079

\section{Results and Discussions}

\section{Effect of carbon and nitrogen source on PHA biosynthesis in shake flask}

E. coli JM109 is known to be a host that can effectively express the enzyme, and capable to synthesize various PHAs with different monomer compositions without degradation [30]. The mechanism for PHA biosynthesis in E. coli is different from other bacteria, where nutrient limiting condition is not necessary for PHA production [31]. Thus, nitrogen source provides especially for cell growth. However, Steinbüchel and Pieper [32] reported that recombinant A. eutrophus is capable for $\mathrm{P}$ (3HB-co-3HV) copolymer accumulation, from various unrelated carbon sources, when nitrogen is limited and carbon sources are supplementing in excess. In this study, the effect of different carbon sources on cell growth and PHA production from the recombinant $E$. coli JM109 harbouring plasmid pGEM'-phaCABCo, was carried out in the shake flask. The fermentation in the shake flasks was carried out with or without nitrogen source, to examine the effect of nitrogen source on the growth and PHA accumulation of E. coli.

Table 1 shows the cell growth and PHA production of the recombinant E. coli JM109, using different carbon sources (i.e. glucose and mixed acids). It was observed that the recombinant E. coli JM109 preferred glucose compared to mixed acids, as its carbon source for growth. The cell titre showed a significant difference $(p<0.05)$, depending on the initial concentration of carbon source. It can be observed that the cell growth was affected by the initial concentration of glucose, in which higher glucose concentration reduced the CDW formation. However, there was no significant difference on PHA accumulation, when a different type of carbon source was used. There was only a slight increase in PHA accumulation, once glucose was used (Table 1). This may be due to the substrate concentration, inhibitory of the initial amount of glucose used. However, the recombinant still can utilize for PHA biosynthesis. Therefore, the use of higher concentration of glucose $(40 \mathrm{~g} / \mathrm{L})$, not only decreased the cell growth but also $\mathrm{P}(3 \mathrm{HB})$ accumulation (data not shown).

Glucose was utilized for better cell formation and PHA accumulation compared with mixed organic acids, whereby they only affected accumulation of PHA. Nevertheless, declined growth of recombinant E. coli JM109 was observed, in medium containing $10 \mathrm{~g} / \mathrm{L}$ mixed acids supplemented with nitrogen source. The mixed organic acids were consumed more effectively by recombinant without nitrogen supplement, compared to the cultivation under same condition with 1 $\mathrm{g} / \mathrm{L}$ nitrogen source. From Table 1 , it is seen that the recombinant $E$. coli JM109 was able to utilize mixed organic acids for $\mathrm{P}$ (3HB-co-3HV) copolymer accumulation. A similar observation was also reported recently [17]. This is in agreement with previous finding by Chien et al. [33], whereby it was discussed that the presence of propionic acid in the fermentation broth, contributed to $\mathrm{P}$ (3HB-co-3HV) copolymer biosynthesis $[17,33]$

Table 1 and Table 2 show the effect of nitrogen on the CDW and PHA accumulation of the recombinant E. coli JM109. When the recombinant E. coli JM109 was cultivated in the MS medium containing nitrogen source $\left[1 \mathrm{~g} / \mathrm{L}\right.$ of $\left.\left(\mathrm{NH}_{4}\right)_{2} \mathrm{SO}_{4}\right]$ and $10 \mathrm{~g} / \mathrm{L}$ glucose, CDW increased from $1.5 \mathrm{~g} / \mathrm{L}$ (Table 1, experiment 1) to $2.3 \mathrm{~g} / \mathrm{L}$ (Table 2, experiment 1) and PHA content increased from $34 \%$ to $46 \%$, respectively. Meanwhile, Lee and Chang [34] reported that addition of complex nitrogen sources in the fermentation medium, could significantly enhance the concentration of accumulated P $(3 \mathrm{HB})$, in both shake flasks and fed-batch fermentation of the recombinant $E$. coli harbouring the genes from Alcaligenes eutrophus. Once again, the CDW and PHA contents of increased amount of glucose $(20 \mathrm{~g} / \mathrm{L}) \mathrm{did}$ not show any significant difference to $10 \mathrm{~g} / \mathrm{L}$ glucose as the carbon source (Table 2, experiment 2).

The results showed that both CDW and PHA content were improved, when the fermentation was supplemented with $\left(\mathrm{NH}_{4}\right)_{2} \mathrm{SO}_{4}$ This indicates that PHA biosynthesis in recombinant E. coli happened during growth, and not under nutrient limitation like those phenomenon observed in wild type PHA producer such as $C$. necator [31]. However, the complex medium could reduce the $\mathrm{P}(3 \mathrm{HB})$ accumulation while supplementation of small amount of complex nitrogen sources [34], amino acids or oleic acids [35] could improve the $\mathrm{P}(3 \mathrm{HB})$ synthesised. The addition of nitrogen sources will increase the amount of acetyl-CoA and/or NADPH in the PHA metabolic pathway for PHA production [35,36]. Chien et al. [33] reported that total CDW of recombinant $E$. coli was increased as the increment of yeast extract, with glucose as carbon source in medium. The increased concentration of yeast extract also, led to improve the PHA content in the recombinant cells. Hence, the CDW and PHA content in the cells can be improved under regular carbon and nitrogen supplement in recombinant cells.

\begin{tabular}{|c|c|c|c|c|c|c|c|}
\hline \multirow[t]{2}{*}{ Experiment } & \multirow{2}{*}{$\begin{array}{l}\text { Carbon } \\
\text { source }\end{array}$} & \multirow{2}{*}{$\begin{array}{l}\text { Conc. } \\
\text { g/L }\end{array}$} & \multirow{2}{*}{$\begin{array}{l}\text { Remaining carbon source } \\
\qquad(\mathrm{g} / \mathrm{L})\end{array}$} & \multirow{2}{*}{$\begin{array}{l}\text { CDW } \\
(\mathrm{g} / \mathrm{L})\end{array}$} & \multirow{2}{*}{$\begin{array}{l}\text { PHA content" } \\
\text { (wt } \%)\end{array}$} & \multicolumn{2}{|c|}{$\begin{array}{l}\text { PHA composition" } \\
\text { (mol\%) }\end{array}$} \\
\hline & & & & & & $3 \mathrm{HB}$ & $3 \mathrm{HV}$ \\
\hline Control'II & Mixed' acids & 10 & NA & $0.4 \pm 0.07$ & ND & ND & ND \\
\hline Control'v & Glucose' & 10 & NA & $1.6 \pm 0.3$ & $46.1 \pm 3.8$ & 100 & 0 \\
\hline 1 & \multirow{2}{*}{ Glucose' } & 10 & 0.3 & $1.5^{\mathrm{a}} \pm 0.2$ & $34.3^{a} \pm 1.0$ & 100.0 & 0 \\
\hline 2 & & 20 & 0.7 & $0.8^{b} \pm 0.03$ & $34.8^{a} \pm 0.5$ & 100.0 & 0 \\
\hline 3 & Mixed acids' & 10 & 5.4 & $0.5^{c} \pm 0.01$ & $32.0^{\mathrm{a}} \pm 2.2$ & 97.7 & 2.3 \\
\hline
\end{tabular}

CDW, cell dry weight; PHA, polyhydroxyalkanoates; 3HB, (3-hydroxybutyrate); 3HV, (3-hydroxyvelerate); ND, not detected; NA, not analyzed.

Data shown are means of triplicates. Mean data accompanied by different superscript letters, are significantly different (Duncan's Multiple Range Test, $p<0.05)$.

' Incubated for $48 \mathrm{~h}$ at $37^{\circ} \mathrm{C}$ at $200 \mathrm{rpm}$ in MS medium, without $1 \mathrm{~g} / \mathrm{L}\left(\mathrm{NH}_{4}\right)_{2} \mathrm{SO}_{4}$ supplemented with $50 \mu \mathrm{g} / \mathrm{mL}$ of ampicillin. Sterilized glucose was added during inoculation, while mixed acids were supplied directly prior to autoclaving and $\mathrm{pH}$ was adjusted using $1 \mathrm{M} \mathrm{NaOH}$.

"PHA content in lyophilized cells was determined by GC.

"I' Escherichia coli JM109 was cultivated in MS medium with mixed acids as negative control.

${ }^{\mathrm{IV}}$ Escherichia coli JM109 harbouring pGEM'-phbCAB ${ }_{\mathrm{Re}}$, PHA biosynthesis gene from C. necator was cultivated in MS medium with 10 g/L glucose as positive control.

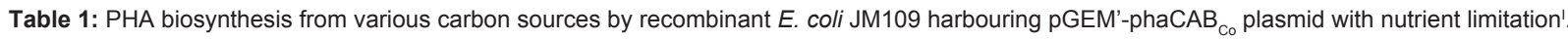


Citation: Yee LN, Mumtaz T, Mohammadi M, Phang LY, Ando Y, et al. (2012) Polyhydroxyalkanoate Synthesis by Recombinant Escherichia coli JM109 Expressing PHA Biosynthesis Genes from Comamonas sp. EB172. J Microb Biochem Technol 4: 103-110. doi:10.4172/19485948.1000079

On the other hand, declined growth of the recombinant $E$. coli JM109 was observed, in the medium containing mixed acids supplemented with nitrogen source. This may be due to the inhibitory effect of mixed organic acids, in the ratio of 3:1:1 (acetic acid: propionic acid: n-butyric acid). Even with the model organism, C. necator, the maximum CDW and PHA contents using $3 \mathrm{~g} / \mathrm{L}$ mixed acids in the ratio of 3:1:1 (acetic acid: propionic acid: n-butyric acid) were shown to be 1.1 $\mathrm{g} / \mathrm{L}$ and $58.2 \mathrm{wt} \%$, respectively, after $41 \mathrm{~h}$ of cultivation [37]. However, it has to be noted that the tolerance level of mixed acids differs among bacterial species, and PHA accumulation in native producers such as in C. necator, which require nitrogen limitation.

As shown in Table 2, the PHA accumulation was slightly better, when the MS medium containing mixed organic acids was supplemented with $\left(\mathrm{NH}_{4}\right)_{2} \mathrm{SO}_{4}$. It was observed that with the presence of nitrogen in the culture medium, PHA accumulation was slightly increased from $32 \%$ to $37 \%$, but the $3 \mathrm{HV}$ monomer content was decreased (Table 2, experiment 3). Similar observations were reported by Kim et al. [38] in Alcaligenes sp. SH-69, in which nitrogen source was found to affect the chemical composition of polymer. Chien et al. [33] reported that the increase in concentration of yeast extract in cultivation medium had decreased the $3 \mathrm{HV}$ formation in $\mathrm{P}$ (3HB-co3HV) copolymer produced.

In order to examine the effect of nitrogen and $3 \mathrm{HV}$ molar fraction of $\mathrm{P}(3 \mathrm{HB}-\mathrm{co}-3 \mathrm{HV})$ copolymer, the recombinant E. coli JM109 was grown in a different concentration of $\left(\mathrm{NH}_{4}\right)_{2} \mathrm{SO}_{4}$, with equal amount of mixed acids at $10 \mathrm{~g} / \mathrm{L}$ in the shake flask. As shown in Table 3, more $3 \mathrm{HV}$ can be produced with lower supplementation of the nitrogen source. The highest $3 \mathrm{HV}$ fraction of $2.65 \mathrm{~mol} \%$ was observed, with an addition of $0.5 \mathrm{~g} / \mathrm{L}\left(\mathrm{NH}_{4}\right)_{2} \mathrm{SO}_{4}(\mathrm{C} / \mathrm{N}$ ratio at 42.1$)$ and with low CDW. A C/N ratio of more than $21 \mathrm{~mol} / \mathrm{mol}$ enhanced the cell growth and PHA accumulation, whereas at lower $\mathrm{C} / \mathrm{N}$ ratio, both the $3 \mathrm{HV}$ and $\mathrm{CDW}$ were decreased (Table 3). On the other hand, PHA content was the highest at $21 \mathrm{~mol} / \mathrm{mol} \mathrm{C} / \mathrm{N}$ ratios, using mixed organic acids. Obviously, the $\mathrm{CDW}$ and fraction of $3 \mathrm{HV}$ monomer of the recombinant $E$. coli were decreased by $1 \mathrm{~g} / \mathrm{L}\left(\mathrm{NH}_{4}\right)_{2} \mathrm{SO}_{4}$ addition, compared to lower concentration of nitrogen addition. Hence, excess carbon sources and limiting nitrogen supplementation condition were needed for synthesizing the copolymer, and affecting the growth of the constructed recombinant E. coli JM109.

\section{Batch fermentation of recombinant $E$. coli JM109 in $2 \mathrm{~L}$ bioreactor}

Batch fermentation was performed in a $2 \mathrm{~L}$ bioreactor, to get higher cell and PHA concentrations under controlled condition, compared to the shake flask fermentation. As shown in Table 1 and Table 2, the availability of propionic acids in the mixed organic acids, in the medium, could lead to the biosynthesis of $3 \mathrm{HV}$ monomer for the accumulated polymer, while the utilisation of glucose in the medium could improve the cell growth. Moreover, the addition of nitrogen was able to increase the CDW and PHA accumulation, using glucose in the medium as substrate. Table 4 illustrates the kinetic parameter values

\begin{tabular}{|c|c|c|c|c|c|c|c|}
\hline \multirow[t]{2}{*}{ Experiment } & \multirow{2}{*}{$\begin{array}{l}\text { Carbon } \\
\text { source }\end{array}$} & \multirow{2}{*}{$\begin{array}{l}\text { Conc. } \\
\text { (g/L) }\end{array}$} & \multirow{2}{*}{$\begin{array}{l}\text { Remaining carbon source } \\
\qquad(\mathrm{g} / \mathrm{L})\end{array}$} & \multirow{2}{*}{$\begin{array}{l}\text { CDW } \\
(g / L)\end{array}$} & \multirow{2}{*}{$\begin{array}{l}\text { PHA content" } \\
\quad(w t \%)\end{array}$} & \multicolumn{2}{|c|}{$\begin{array}{l}\text { PHA composition" } \\
(\mathrm{mol} \%)\end{array}$} \\
\hline & & & & & & $3 \mathrm{HB}$ & $3 \mathrm{HV}$ \\
\hline Control"II & Mixed' acids & 10 & NA & $0.6 \pm 0.07$ & ND & ND & ND \\
\hline Control'v & Glucose' & 10 & NA & $1.7 \pm 0.2$ & $48.0 \pm 1.6$ & 100 & 0 \\
\hline 1 & \multirow{2}{*}{ Glucose' } & 10 & 0.0 & $2.3^{a} \pm 0.03$ & $46.4^{a} \pm 2.6$ & 100 & 0 \\
\hline 2 & & 20 & 0.5 & $2.3^{a} \pm 0.06$ & $44.1^{a} \pm 8.1$ & 100 & 0 \\
\hline 3 & Mixed acids' & 10 & 7.3 & $0.2^{b} \pm 0.01$ & $37.7^{\mathrm{a}} \pm 1.8$ & 99.7 & 0.3 \\
\hline
\end{tabular}

CDW, cell dry weight;PHA, polyhydroxyalkanoates; 3HB, (3-hydroxybutyrate); 3HV, (3-hydroxyvelerate); ND, not detected; NA, not analyzed.

Data shown are means of triplicates. Mean data accompanied by different superscript letters, are significantly different (Duncan's Multiple Range Test, $p<0.05$ ).

IIncubated for $48 \mathrm{~h}$ at $37^{\circ} \mathrm{C}$ at $200 \mathrm{rpm}$ in MS medium containing $1 \mathrm{~g} / \mathrm{L}\left(\mathrm{NH}_{4}\right)_{2} \mathrm{SO}_{4}$ supplemented with $50 \mu \mathrm{g} / \mathrm{mL}$ of ampicillin. Sterilized glucose was added during inoculation, while mixed acids were supplied directly, prior to autoclaving and $\mathrm{pH}$ was adjusted using $1 \mathrm{M} \mathrm{NaOH}$.

"PHA content in lyophilized cells was determined by GC

II" Escherichia coli JM109 was cultivated in MS medium with mixed acids as negative control.

IV Escherichia coli JM109 harbouring pGEM'-phbCAB ${ }_{\mathrm{Re}}, \mathrm{PHA}$ biosynthesis gene from C. necator was cultivated in MS medium with $10 \mathrm{~g} / \mathrm{L}$ glucose as positive control.

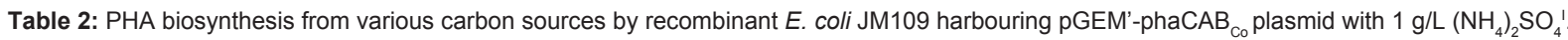

\begin{tabular}{|c|c|c|c|c|}
\hline Experiment & $\left(\mathrm{NH}_{4}\right)_{2} \mathrm{SO}_{4}(\mathrm{~g} / \mathrm{L})$ & $\mathrm{C} / \mathrm{N}$ & CDW (g/L) & $3 \mathrm{HV}$ mol fraction (\%)" \\
\hline Control"II & 0.0 & 0 & $0.4 \pm 0.07$ & ND \\
\hline Controlv & 0.0 & 0 & $0.5 \pm 0.08$ & $17.85 \pm 0.49$ \\
\hline 1 & 0.0 & 0 & $0.45 \pm 0.00^{\mathrm{a}}$ & $2.32 \pm 0.02^{\mathrm{b}}$ \\
\hline 2 & 0.5 & 42.1 & $0.36 \pm 0.04^{a}$ & $2.65 \pm 0.11^{\mathrm{a}}$ \\
\hline 3 & 1.0 & 21.0 & $0.24 \pm 0.00^{\mathrm{b}}$ & $0.31 \pm 0.09^{c}$ \\
\hline
\end{tabular}

$\mathrm{C} / \mathrm{N}$, carbon to nitrogen ratio; CDW, cell dry weight; 3HV, (3-hydroxyvelerate).

Data shown are means of triplicates. Mean data accompanied by different superscript letters, are significantly different (Duncan's Multiple Range Test, $p<0.05$ ).

'Incubated for $48 \mathrm{~h}$ at $37^{\circ} \mathrm{C}$ at $200 \mathrm{rpm}$ in MS medium with different amount $\left(\mathrm{NH}_{4}\right)_{2} \mathrm{SO}_{4}$ supplemented with $50 \mu \mathrm{g} / \mathrm{mL}$ of ampicillin. Mixed acids (10 g/L) were supplied directly, prior to autoclaving and $\mathrm{pH}$ was adjusted using $1 \mathrm{M} \mathrm{NaOH}$.

"PHA content in lyophilized cells was determined by GC

"IEscherichia coli JM109 was cultivated in MS medium with mixed acids as negative control.

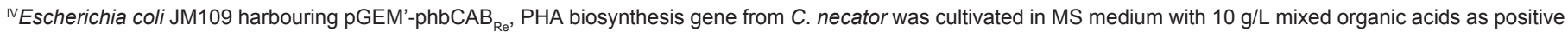
control.

Table 3: The cell dry weight $(\mathrm{g} / \mathrm{L})$ and $3 \mathrm{HV}$ molar fraction (\%) using different amount of $\left(\mathrm{NH}_{4}\right)_{2} \mathrm{SO}_{4}$ with $10 \mathrm{~g} / \mathrm{L}$ mixed organic acids as carbon sourcel. 
Citation: Yee LN, Mumtaz T, Mohammadi M, Phang LY, Ando Y, et al. (2012) Polyhydroxyalkanoate Synthesis by Recombinant Escherichia coli JM109 Expressing PHA Biosynthesis Genes from Comamonas sp. EB172. J Microb Biochem Technol 4: 103-110. doi:10.4172/19485948.1000079

for batch fermentation, using 10 and $20 \mathrm{~g} / \mathrm{L}$ glucose as substrate with $0.5 \mathrm{~g} / \mathrm{L}\left(\mathrm{NH}_{4}\right)_{2} \mathrm{SO}_{4}(37.7$ and $75.5 \mathrm{C} / \mathrm{N}$, respectively). The recombinant E. coli JM109 was cultivated in $10 \mathrm{~g} / \mathrm{L}$ and $20 \mathrm{~g} / \mathrm{L}$ glucose supplemented with $0.5 \mathrm{~g} / \mathrm{L}, 1 \mathrm{~g} / \mathrm{L}$ and without $\left(\mathrm{NH}_{4}\right)_{2} \mathrm{SO}_{4}$. However, higher productivity

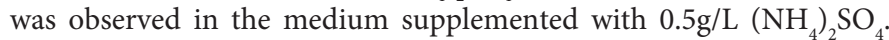
Although, the PHA yield based on PHA biosynthesis per cell (g PHA/g cell) in the fermentation using 10 and $20 \mathrm{~g} / \mathrm{L}$ of glucose was similar, the substrate utilization coefficient, $\mathrm{Yp} / \mathrm{s}$ (g PHA/g substrate), and productivity were higher when $20 \mathrm{~g} / \mathrm{L}$ glucose was used as the sole carbon source. Bioreactor fermentation performed at controlled $\mathrm{pH}$ and DO can certainly improve the biomass and PHA production, as compared to shake flask fermentation with only controlled initial $\mathrm{pH}$. The lower level of PHA biosynthesis using $10 \mathrm{~g} / \mathrm{L}$ glucose could be due to rapid exhaustion of glucose concentration (less than $1 \mathrm{~g} / \mathrm{L}$ ) after $18 \mathrm{~h}$ cultivation. Slightly higher PHA biosynthesis per cell (g PHA/g cell) of the recombinant $E$. coli JM109 was obtained in the fermentation using $10 \mathrm{~g} / \mathrm{L}$ glucose. However, the best productivity, $0.16 \mathrm{~g}$ PHA/ (L.h), was observed in medium with $20 \mathrm{~g} / \mathrm{L}$ glucose supplemented with $0.5 \mathrm{~g} / \mathrm{L}$ $\left(\mathrm{NH}_{4}\right)_{2} \mathrm{SO}_{4}$.

Figure 1 and 2 shows the profile for the OD, CDW and PHA content, for the batch reaction using $10 \mathrm{~g} / \mathrm{L}$ and $20 \mathrm{~g} / \mathrm{L}$ glucose with $0.5 \mathrm{~g} / \mathrm{L}\left(\mathrm{NH}_{4}\right)_{2} \mathrm{SO}_{4}$. Higher concentration of glucose, the cell growth was slower than the PHA accumulation compared to the lower glucose concentration, where the cell growth almost proportional to the PHA accumulation. The recombinant bacteria preferred to produce carbon compound intracellularly, and later cell metabolism with lower concentration of carbon source.

On the other hand, batch fermentation was performed by feeding $10 \mathrm{~g} / \mathrm{L}$ mixed organic acids with $1 \mathrm{~g} / \mathrm{L}\left(\mathrm{NH}_{4}\right)_{2} \mathrm{SO}_{4}$, to observe the ability of a recombinant cells that can utilise mixed organic acids derived from POME, rather than glucose as substrate. However, the experiment further proved that the mixed organic acids were not an ideal sole carbon substrate for PHA accumulation, in batch fermentation. On the contrary, when mixed organic acids were used as the carbon source, lower productivity and yield [0.003g PHA/ (L.h-1) and 0.03g PHA/g substrate, respectively] were achieved. During batch fermentation with mixed organic acids, $1.9 \mathrm{~mol} \%$ of $3 \mathrm{HV}$ monomer fraction was observed at $30 \mathrm{~h}$ cultivation time. The $3 \mathrm{HV}$ monomer was decreased to $1.1 \mathrm{~mol} \%$

\begin{tabular}{|c|c|c|c|}
\hline \multirow[t]{2}{*}{ Kinetic parameter values } & \multicolumn{3}{|c|}{ Glucose (g/L) } \\
\hline & $20^{\prime}$ & 10 & 20 \\
\hline$t(h)$ & 24 & 24 & 24 \\
\hline PHA content (\%wt) & - & 65.34 & 62.65 \\
\hline $\mathrm{X}_{\mathrm{m}}(\mathrm{g}$ cell/L) & 2.65 & 3.03 & 5.9 \\
\hline$P_{m}(g \mathrm{PHA} / \mathrm{L})$ & - & 2.05 & 3.77 \\
\hline$\mu_{m}\left(h^{-1}\right)$ & 0.13 & 0.08 & 0.19 \\
\hline $\mathrm{Y}_{\mathrm{x} / \mathrm{s}}(\mathrm{g}$ cell/g substrate $)$ & - & 0.43 & 0.64 \\
\hline $\mathrm{Y}_{\mathrm{p} / \mathrm{s}}(\mathrm{g} \mathrm{PHA} / \mathrm{g}$ substrate $)$ & - & 0.29 & 0.41 \\
\hline $\mathrm{Y}_{\mathrm{p} / \mathrm{x}}(\mathrm{g} \mathrm{PHA} / \mathrm{g}$ cell $)$ & - & 0.68 & 0.64 \\
\hline $\mathrm{P}_{\mathrm{r}}\left(\mathrm{g} \mathrm{PHA} /\left(\mathrm{L} \cdot \mathrm{h}^{-1}\right)\right)$ & - & 0.09 & 0.16 \\
\hline
\end{tabular}

$\mathrm{t}$, time at the maximum cell concentration $(\mathrm{h}) ; \mathrm{X}_{\mathrm{m}}$, maximum cell concentration $(\mathrm{g}$ cell/L); $P_{m}$, maximum PHA concentration ( $\left.\mathrm{g} \mathrm{PHA} / \mathrm{L}\right) ; \mu_{m}$, maximum specific growth rate $\left(h^{-1}\right) ; Y_{x / s}$, growth yield coefficient ( $g$ cell/g substrate); $Y_{p / s}, P H A$ yield based on the substrate utilized coefficient (g PHA /g substrate); $Y_{p / x}, P H A$ biosynthesis per cell (g PHA/g cell); $\mathrm{P}_{\mathrm{r}}$, PHA productivity (g PHA/(L.h $h^{-1}$ ).

' Escherichia coli JM109 was cultivated in MS medium with $20 \mathrm{~g} / \mathrm{L}$ glucose as negative control.

Table 4: Comparison of kinetic parameter values of PHA biosynthesis in $2 \mathrm{~L}$ bioreactor using glucose as carbon source.

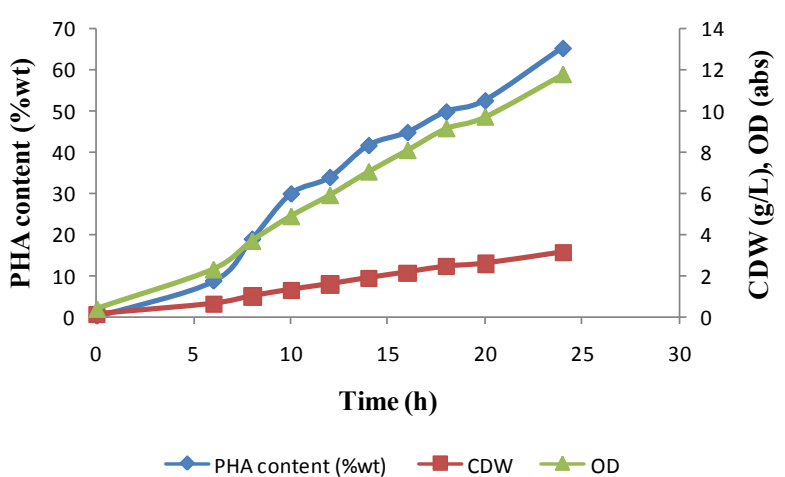

Figure 1: Profile of $\mathrm{OD}, \mathrm{CDW}$ and $\mathrm{PHA}$ content during the batch fermentation using $10 \mathrm{~g} / \mathrm{L}$ glucose with $0.5 \mathrm{~g} / \mathrm{L}\left(\mathrm{NH}_{4}\right)_{2} \mathrm{SO}_{4}$.

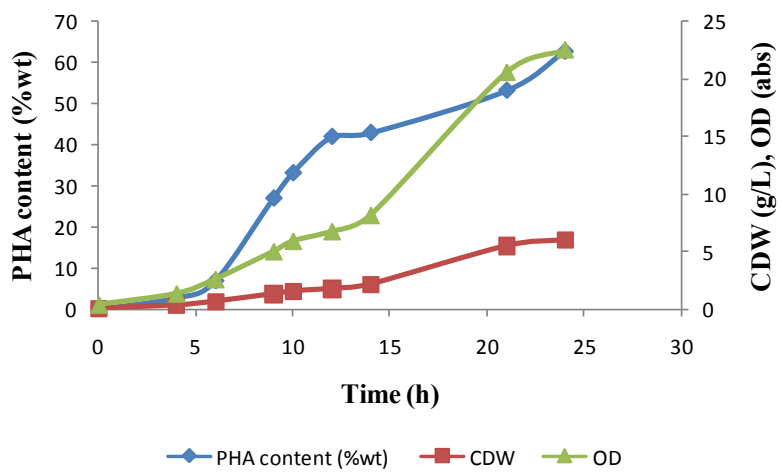

Figure 2: Profile of $\mathrm{OD}, \mathrm{CDW}$ and $\mathrm{PHA}$ content during the batch fermentation using $20 \mathrm{~g} / \mathrm{L}$ glucose with $0.5 \mathrm{~g} / \mathrm{L}\left(\mathrm{NH}_{4}\right)_{2} \mathrm{SO}_{4}$.

at $33 \mathrm{~h}$, at the end of the fermentation with the increasing of PHA content from 22.5 to $32.2 \mathrm{wt} \%$, respectively (data not shown). Table 5 shows some recombinant $E$. coli which are used for production of $\mathrm{P}(3 \mathrm{HB}-\mathrm{co}-$ $3 \mathrm{HV})$. The mixed organic acids were mainly fed for accumulation of copolymer, and the total PHA accumulated comparable with previous study. Therefore, mixed organic acids derived from POME can be used as an alternative carbon source, as the recombinant E. coli JM109 can still utilize this less favourable substrate for PHA accumulation. For this purpose, a proper fermentation strategy using $2 \mathrm{~L}$ bioreactor necessary established to produce co-polymers, using mixed organic acids by the designed recombinant.

\section{Polymer characterization}

The methyl esters of the constituent hydroxyalkanoic acids were analyzed using GC. The GC result showed that PHA synthesized from the recombinant E. coli JM109, contained 3HV monomer fraction. Hence, $1 \mathrm{H}$ NMR analysis was carried out to determine the chemical structure of the polymer. Figure 1 shows the $1 \mathrm{H}$ NMR spectrum of polymer produced by the recombinant E. coli JM109, from the 2 $\mathrm{L}$ bioreactor. The spectrum confirmed that the PHA synthesized by the recombinant $E$. coli JM109 in batch fermentation, using 10 $\mathrm{g} / \mathrm{L}$ mixed organic acids with $1 \mathrm{~g} / \mathrm{L}$ nitrogen supplementation, was a $\mathrm{P}$ (3HB-co-3HV) copolymer. The present signals for $3 \mathrm{HB}$ molar fraction were identified at $1.27 \mathrm{ppm}, 2.4-2.6 \mathrm{ppm}$ and $5.27 \mathrm{ppm}$, which represent methyl $(\mathrm{CH} 3)$, methylene $(\mathrm{CH} 2)$ and methine $(\mathrm{CH})$ groups, respectively. The signals of $3 \mathrm{HV}$ monomer were attributed by the methyl signal, shown by a triplet at $0.9 \mathrm{ppm}$. Other characteristic signals 
Citation: Yee LN, Mumtaz T, Mohammadi M, Phang LY, Ando Y, et al. (2012) Polyhydroxyalkanoate Synthesis by Recombinant Escherichia coli JM109 Expressing PHA Biosynthesis Genes from Comamonas sp. EB172. J Microb Biochem Technol 4: 103-110. doi:10.4172/19485948.1000079

\begin{tabular}{|l|l|l|l|l|l|}
\hline Organism & Substrate & Mode of operation & CDW (g/L) & PHA content (\%wt) \\
\hline Recombinant E. coli & Mixed organic acids & Shake flask & 0.2 & 37.7 \\
\hline Recombinant E. coli & Mixed organic acids & Batch & 0.3 & 32.26 \\
\hline Recombinant E. coli & $\begin{array}{l}\text { Glucose + sodium } \\
\text { propionate }\end{array}$ & Shake flask & 3.3 & 37.6 \\
\hline Escherichia coli XL10-Gold & Glucose + propionate & Fed-batch & 1.35 & 8.6 \\
\hline E. coli BW25113 & Glucose & Shake flask & 2.83 & 18.96 \\
\hline Recombinant E. coli & Glucose + propionate & Shake flask & 18.0 & 29.5 \\
\hline
\end{tabular}

Table 5: Production of $\mathrm{P}(3 \mathrm{HB}-\mathrm{co}-3 \mathrm{HV})$ using recombinant $E$. coli.

of $3 \mathrm{HV}$ unit cannot be seen, which could either due to low intensity or overlapping with $3 \mathrm{HB}$ characteristic signal, such as methylene signals at 2.4-2.6 ppm. Thus, based on the GC and $1 \mathrm{H}$ NMR analyses, it was confirmed that the polymer was $\mathrm{P}$ (3HB-co-3HV) copolymer, produced from mixed organic acids as the sole carbon source.

Table 6 shows the molecular weight and polydispersity index (PDI) of chloroform-extracted polymers produced by the recombinant $E$. coli JM109, from the $2 \mathrm{~L}$ bioreactor with glucose or mixed organic acids as the carbon source. Molar mass is an important factor determining physical properties of polymers, and is known to vary with substrate and culture conditions [42]. The average numbers of molecular weight $(\mathrm{Mn})$ of the $\mathrm{P}(3 \mathrm{HB})$ recovered from A. eutrophus and the recombinant $E$. coli strain, by chloroform extraction was reported to be $1.2 \times 106 \mathrm{Da}$ and $1.53 \times 106 \mathrm{Da}$, respectively [43]. In this study, the weight average of molecular weight $(\mathrm{Mw})$ of the polymer accumulated by the recombinant $E$. coli JM109 was in the range of $8.5 \times 105$ to 1.4 $\mathrm{x} 106 \mathrm{Da}$. The Mw of the polymer was not affected by the difference in PHA content of the cells. However, the type of carbon source and the different concentration of substrate could affect the Mw of the polymers. Under the same cultivation condition, the PHA produced from $10 \mathrm{~g} / \mathrm{L}$ glucose, represented the highest $\mathrm{Mw}$ compared to 20 $\mathrm{g} / \mathrm{L}$ glucose and $10 \mathrm{~g} / \mathrm{L}$ mixed organic acids. These molecular weights were found to be higher than the PHA polymer synthesized by the recombinant E. coli, expressing a different PHA synthase $[44,45]$. The highest $\mathrm{Mw}$ was achieved from batch fermentation with $10 \mathrm{~g} / \mathrm{L}$ glucose, whereas the lowest PDI was obtained from the fermentation of mixed acids (Table 6). A high molecular weight with a low polydispersity is usually desired in the production of commodity thermoplastics. A molecular weight of $6 \times 105 \mathrm{Da}$ or above, is considered acceptable for thermoplastic applications of scl-P(3HB-co-3HV) [46]. On the other hand, in coatings, pressure-sensitive adhesives, polymer binding agents

\begin{tabular}{|l|l|l|l|l|}
\hline Experiment & Carbon source & $\begin{array}{l}M_{n}^{\prime \prime} \\
(\mathrm{kDa})\end{array}$ & $\begin{array}{l}M_{w}{ }^{\prime \prime} \\
(\mathrm{kDa})\end{array}$ & $\begin{array}{l}\mathrm{PDI} \\
\left(M_{w} / M_{n}\right)\end{array}$ \\
\hline 1 & $10 \mathrm{~g} / \mathrm{L}$ Glucose & 740 & 1440 & 1.95 \\
\hline 2 & $20 \mathrm{~g} / \mathrm{L}$ Glucose & 510 & 1000 & 1.96 \\
\hline 3 & $10 \mathrm{~g} / \mathrm{L}$ Mixed acids & 570 & 850 & 1.50 \\
\hline
\end{tabular}

CDW, cell dry weight; PHA, polyhydroxyalkanoates; 3HB, (3-hydroxybutyrate); $3 \mathrm{HV}$, (3-hydroxyvelerate), $M_{n}$, number average of molecular weight; $M_{w}$, weight average of molecular weight; PDI, polydispersity index.

' cultivated at $37^{\circ} \mathrm{C}, \mathrm{pH} 7$ and DO level was maintained at $30 \%$ in MS medium containing $1 \mathrm{~g} / \mathrm{L}\left(\mathrm{NH}_{4}\right)_{2} \mathrm{SO}_{4}$ supplemented with $50 \mu \mathrm{g} / \mathrm{mL}$ of ampicillin for $24 \mathrm{~h}$. The air flow was kept at $1 \mathrm{vvm}$. Sterilized glucose was added during inoculation while mixed acids were supplied directly, prior to autoclaving and $\mathrm{pH}$ was adjusted using $1 \mathrm{M} \mathrm{NaOH}$

"Determined by GPC analysis

Table 6: Molecular weight and polydispersity of $\mathrm{PHA}$ produced by recombinant

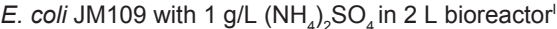

in organic-solvent-free paints and in a range of medical applications, low molecular weights are preferable [47]. Apparently, the PDI value was found to be similar to the values reported for the PHAs synthesized by other bacteria.

\section{Conclusion}

Unlike the wild type Comamonas sp. EB172, the recombinant $E$. coli JM109 was able to utilize both glucose and mixed organic acids, to produce $\mathrm{P}$ (3HB-co-3HV) copolymer. This implies that recombinant $E$. coli JM109 has potential to utilize the waste-stream by-products from oil palm industry, such as mixed acids from POME and/or mixed sugars from oil palm frond juice, for PHA production. From the shake flask and batch fermentation, we know that $\mathrm{P}(3 \mathrm{HB})$ can be accumulated using glucose and mixed organic acids. However, P (3HB-co-3HV) copolymer only accumulated, using mixed organic acids. However, there are two main issues a) the low cell growth and b) production of co-polymer from supplied carbon source. Therefore, development of a fermentation strategy that is capable to cater the issues is necessary. PHA was accumulated intracellularly, therefore, increasing the CDW will basically improve the PHA content. A proper feeding strategy can be suggested, for employing as suitable mode for PHA production with mixed organic acids. Fed-batch cultivation is an industrial preferred mode of operation, in order to achieve high cell density and reduce the substrate inhibitory. Thus, the mixed organic acids concentration can be maintained for biological and metabolic activities, at appropriate level. Fed-batch fermentation may improve CDW, PHA accumulation or $3 \mathrm{HV}$ monomer fraction. On the other hand, genetic modification on threonine pathway or protein engineering on PHA biosynthesis genes, may improve the substrate or enzyme specificity will also be our future focus. The polymer produced from this study has desired molecular weight, suitable for thermoplastic applications. Based on the properties, co-polymer will be preferred in PHA production since it is more valuable in applications.

\section{Acknowledgements}

The authors would like to acknowledge the financial and technical supports provided by the Ministry of Science, Technology and Innovation (MOSTI) Malaysia, Universiti Putra Malaysia, and Japan Society for Promotion of Science (JSPS), Japan. We are grateful for the help provided by Mr Kohtaro Watanabe and Mr Wong Yoke Ming, during the sample analysis.

\section{References}

1. Kim do Y, Park DS, Kwon SB, Chung MG, Bae KS, et al. (2009) Biosynthesis of poly(3-hydroxybutyrate-co-3-hydroxyvalerate) copolyesters with a high molar fraction of 3-hydroxyvalerate by an insect-symbiotic Burkholderia sp. IS-01. J Microbiol 47: 651-656.

2. Sim SJ, Snell KD, Kim BW, Rha CK, Sinskey AJ (2001) Increased poly- $\beta$ hydroxybutyrate (PHB) chain length by the modulation of PHA synthase activity in recombinant Escherichia coli. Biotechnol Lett 23: 2057-2061.

3. Steinbüchel A (2003) Production of rubber-like polymers by microorganisms. Curr Opin Microbiol 6: 261-270. 
Citation: Yee LN, Mumtaz T, Mohammadi M, Phang LY, Ando Y, et al. (2012) Polyhydroxyalkanoate Synthesis by Recombinant Escherichia coli JM109 Expressing PHA Biosynthesis Genes from Comamonas sp. EB172. J Microb Biochem Technol 4: 103-110. doi:10.4172/19485948.1000079

4. Sudesh K, Bhubalan K, Chuah JA, Kek YK, Kamilah H, et al. (2011) Synthesis of polyhydroxyalkanoate from palm oil and some new applications. Appl Microbiol Biotechnol 89: 1373-1386.

5. Surabhi N, Venu Gopal SK, Priti S (2008)Bioproduction of polyhydroxyalkanoates from bacteria: a metabolic approach. World J Microbiol Biotechnol 24: 23072314.

6. Sudesh K, Abe H, Doi Y (2000) Synthesis, structure and properties of polyhydroxyalkanoates: biological polyester. Prog Polym Sci 25: 1503-1555.

7. Khanna S, Srivastava AK (2005) Recent advances in microbial polyhydroxyalkanoates. Process Biochem 40: 607-619.

8. Li R, Zhang H, Qi Q (2007) The production of polyhydroxyalkanoates in recombinant Escherichia coli. Bioresour Technol 98: 2313-2320.

9. Verlinden RA, Hill DJ, Kenward MA, Williams CD, Radecka I (2007) Bacterial synthesis of biodegradable polyhydroxyalkanoates. J Appl Microbiol 102: 14371449.

10. Mumtaz T, Abd-Aziz S, Yee PL, Yunus WMZW, Shirai Y, et al. (2010) Synthesis, Characterization, and Structural Properties of Intracellular Copolyester Poly(3hydroxybutyrate-co-3-hydroxyvalerate) Produced by Comamonas sp. EB 172 from Renewable Resource. International journal of polymer analysis and characterization 15: 329-340.

11. Mumtaz T, Yahaya NA, Abd-Aziz S, Rahman NAA, Yee PL, et al. (2010) Turning waste to wealth-biodegradable plastics polyhydroxyalkanoates from palm oil mill effluent- a Malaysian perspective. J Clean Prod 18: 1393-1402.

12. Zakaria MR, Abd-Aziz S, Ariffin H, Rahman NAA, Yee PL, et al. (2008) Comamonas sp. EB172 isolated from digester treating palm oil mill effluent as potential polyhydroxyalkanoate (PHA) producer. African Journal of Biotechnology 7: 4118-4121.

13. Zakaria MR, Ariffin H, Johar NAM, Abd-Aziz S, Nishida H, et al. (2010) Biosynthesis and characterization of poly(3-hydroxybutyrate-co-3hydroxyvalerate) copolymer from wild-type Comamonas sp. EB172. Polym Degrad Stab 95: 1382-1386.

14. Zakaria MR, Tabatabaei M, Ghazali FM, Abd-Aziz S, Shirai Y, et al. (2010) Polyhydroxyalkanoate production from anaerobically treated palm oil mill effluent by new bacterial strain Comamonas sp. EB172. World J Microbio Biotechnol 26: 767-774.

15. Mohammadi M, Hassan MA, Phang LY, Shirai Y, Che Man H, et al. (2012) Efficient Polyhydroxyalkanoate Recovery from Recombinant Cupriavidus necator by Using Low Concentration of $\mathrm{NaOH}$. Environ Eng Sci 29: 783-789.

16. Mohammadi M, Hassan MA, Shirai $\mathrm{Y}$, Che Man H, Ariffin $\mathrm{H}$, et al. (2012) Separation and Purification of Polyhydroxyalkanoates from Newly Isolated Comamonas sp. EB172 by Simple Digestion with Sodium Hydroxide. Sep Sci Technol 47: 534-541.

17. Yee LN, Chuah JA, Chong ML, Phang LY, Raha AR, et al. (2012) Molecular characterisation of phaCAB from Comamonas sp. EB172 for functional expression in Escherichia coli JM109. Microbiol Res.

18. Song S, Hein S, Steinbüchel A (1999) Production of poly(4-hydroxybutyric acid) by fed-batch cultures of recombinant strains of Escherichia coli. Biotechnol Lett 21: 193-197.

19. Valentin HE, Dennis D (1997) Production of poly(3hydroxybutyrate-co4-hydroxybutyrate) in recombinant Escherichia coli grown on glucose. J Biotechnol 58: 33-38

20. Langenbach S, Rehm BH, Steinbüchel A (1997) Functional expression of the PHA synthase gene phaC1 from Pseudomonas aeruginosa in Escherichia colt results in poly(3-hydroxyalkanoate) synthesis. FEMS Microbiol Lett 150: 303309

21. Park SJ, Ahn WS, Green PR, Lee SY (2001) Biosynthesis of poly(3hydroxybutyrate-c0-3-hydroxyvalerate-c0-3-hydroxyhexanoate) metabolically engineered Escherichia coli strains. Biotechnol Bioeng 74: 81-86.

22. Fukui T, Doi Y (1997) Cloning and analysis of the poly(3-hydroxybutyrate-co-3hydroxyhexanoate) biosynthesis genes of Aeromonas caviae. J Bacteriol 179: 4821-4830.

23. Fukui T, Shiomi N, Doi Y (1998) Expression and characterization of (R)-specific enoyl coenzyme A hydratase involved in polyhydroxyalkanoate biosynthesis by Aeromonas caviae. J Bacteriol 180: 667-673.
24. Chen GQ (2009) A microbial polyhydroxyalkanoates (PHA) based bio- and materials industry. Chem Soc Rev 38: 2434-2446.

25. Zahari MA, Zakaria MR, Ariffin H, Mokhtar MN, Salihon J, et al. (2012) Renewable sugars from oil palm frond juice as an alternative novel fermentation feedstock for value-added products. Bioresour Technol 110: 566-571.

26. Yee PL, Hassan MA, Shirai Y, Wakisaka M, Abdul Karim MI (2003) Continuous production of organic acids from palm oil mill effluent with sludge recycle by the freezing-thawing method. Journal of Chemical Engineering of Japan 36: 707-710.

27. Braunegg G, Sonnleitner B, Lafferty RM (1978) A rapid gas chromatographic method for the determination of poly- $\beta$-hydroxybutyric acid in microbial biomass. Appl Microbiol Biotechnol 6: 29-37.

28. Amirul AA, Yahya AR, Sudesh K, Azizan MN, Majid MI (2008) Biosynthesis of poly(3-hydroxybutyrate-co-4-hydroxybutyrate) copolymer by Cupriavidus $\mathrm{sp}$. USMAA1020 isolated from Lake Kulim, Malaysia. Bioresour Technol 99: 4903 4909.

29. Ariffin H, Nishida H, Shirai Y, Hassan MA (2008) Determination of multiple thermal degradation mechanisms of poly(3-hydroxybutyrate). Polym Degrad Stab 93: 1433-1439.

30. Mahishi LH, Tripathi G, Rawal SK (2003) Poly(3-hydroxybutyrate) (PHB) synthesis by recombinant Escherichia coli harbouring Streptomyces aureofaciens PHB biosynthesis genes: effect of various carbon and nitrogen sources. Microbiol Res 158: 19-27.

31. Lee SY, Yim KS, Chang HN, Chang YK (1994) Construction of plasmids, estimation of plasmid stability, and use of stable plasmids for the production of poly(3-hydroxybutyric acid) by recombinant Escherichia coli. J Biotechnol 32: $203-211$

32. Steinbuchel A, Pieper U (1992) Production of a copolyester of 3-hydroxybutyric acid and 3-hydroxyvaleric acid from single unrelated carbon sources by a mutant of Alcaligenes eutrophus. Appl Microbiol Biotechnol 37: 1-6.

33. Chien CC, Li HH, Soo PC, Chen SY, Wei YH, et al. (2012) Effects of different substrate composition on biosynthesis of polyhydroxybutyrate-cohydroxyvalerate by recombinant Escherichia coli. Appl Biochem Biotechno 166: 796-804.

34. Lee SY, Chang HN (1994) Effect of complex nitrogen source on the synthesis and accumulation of poly(3-hydroxybutyric acid) by recombinant Escherichia coli in flask and fed-batch cultures. Journal of Polymers and the Environment 2: 169-176.

35. Lee SY, Lee YK, Chang HN (1995) Stimulatory effects of amino acids and oleic acid on poly(3-hydroxybutyric acid) synthesis by recombinant Escherichia coli. Journal of Fermentation and Bioengineering 79: 177-180.

36. Lee IY, Kim MK, Park YH, Lee SY (1996) Regulatory effects of cellula nicotinamide nucleotides and enzyme activities on poly(3-hydroxybutyrate) synthesis in recombinant Escherichia coli. Biotechnol Bioeng 52: 707-712.

37. Yang YH, Brigham CJ, Budde CF, Boccazzi P, Willis LB, et al. (2010) Optimization of growth media components for polyhydroxyalkanoate (PHA) production from organic acids by Ralstonia eutropha. Appl Microbiol Biotechno 87: $2037-2045$

38. Kim GJ, Yun KY, Bae KS, Rhee YH (1992) Accumulation of copolyesters consisting of 3-hydroxybutyrate and 3-hydroxyvalerate by Alcaligenes sp. SH69 in batch culture. Biotechnol Lett 14: 27-32.

39. Liu XW, Wang HH, Chen JY, Li XT, Chen GQ (2009) Biosynthesis of poly(3 hydroxybutyrate-co-3-hydroxyvalerate) by recombinant Escherichia coli harboring propionyl-CoA synthase gene (prpE) or propionate permease gene (prpP). Biochem Eng J 43: 72-77.

40. Jian J, Zhang SQ, Shi ZY, Wang W, Chen GQ, et al. (2010) Production of polyhydroxyalkanoates by Escherichia coli mutants with defected mixed acid fermentation pathways. Appl Microbiol Biotechnol 87: 2247-2256.

41. Chen Q, Wang Q, Wei G, Liang Q, Qi Q (2011) Production in Escherichia coli of poly(3-hydroxybutyrate-co-3-hydroxyvalerate) with differing monomer compositions from unrelated carbon sources. Appl Environ Microbiol 77: 48864893

42. Chen GQ, Page WJ (1994) The effect of substrate on the molecular weight of poly-beta-hydroxybutyrate produced by Azotobacter vinelandii. Biotechnol Let 16: $155-160$. 
Citation: Yee LN, Mumtaz T, Mohammadi M, Phang LY, Ando Y, et al. (2012) Polyhydroxyalkanoate Synthesis by Recombinant Escherichia coli JM109 Expressing PHA Biosynthesis Genes from Comamonas sp. EB172. J Microb Biochem Technol 4: 103-110. doi:10.4172/19485948.1000079

43. Hahn SK, Chang YK, Lee SY (1995) Recovery and characterization of poly(3hydroxybutyric acid) synthesized in Alcaligenes eutrophus and recombinant Escherichia coli. Appl Environ Microb 61: 34-39.

44. Agus J, Kahar P, Hyakutake M, Tomizawa S, Abe H, et al. (2010) Unusual change in molecular weight of polyhydroxyalkanoate (PHA) during cultivation of PHA-accumulating Escherichia coli. Polym Degrad Stab 95: 2250-2254.

45. Tomizawa S, Hyakutake M, Saito Y, Agus J, Mizuno K, et al. (2011) Molecular weight change of polyhydroxyalkanoate (PHA) caused by the PhaC subunit of PHA synthase from Bacillus cereus YB-4 in recombinant Escherichia coli. Biomacromolecules 12: 2660-2666.

46. Braunegg G, Lefebvre G, Genser KF (1998) Polyhydroxyalkanoates biopolyesters from renewable resources: physiological and engineering aspects. J Biotechnol 65: 127-161.

47. Reddy CS, Ghai R, Rashmi, Kalia VC (2003) Polyhydroxyalkanoates: an overview. Bioresour Technol 87: 137-146. 